\title{
MÉGIS MEGTÖRTÉNHET? - SZAKOLY KÖZSÉG ÖNKORMÁNYZATÁNAK ADÓSSÁG-RENDEZÉSI ELJÁRÁSA *
}

\author{
Gyirán Zoltán ${ }^{1}$
}

Az adósságkonszolidációt követöen sokan úgy gondolták, már nem fordulhat elö egyetlen magyar önkormányzattal szemben sem, hogy adósságrendezési eljárásra kerüljön sor. Ez év márciusában azonban Szakoly, majd négy hónappal később Tiszabö Önkormányzatával szemben azonban újabb eljárások kezdödtek. ${ }^{2}$

Jelen irásomban a szakolyi eljárással ${ }^{3}$ kapcsolatosan szeretném megvilágítani, mi is vezethetett a kényszerü megoldási alternativához. Mindig is kíváncsi voltam egy-egy történés hátterére, összetevőire, s azok végsö célját keresve megpróbáltam analizálni a pénzügyi-gazdasági jelenségeket, folyamatokat és eseményeket, eljutva az inszolvencia valószínüsithetö okaihoz. Ebben az esetben is egyfajta rankei kíváncsiság (,Wie es eigentlich geschehen?") él bennem, azaz arra keresem a választ, hogy mi is történt valójában. Persze ez a törekvés nem érhet célt teljes mértékben; mert ahogyan Martin Luther King is megfogalmazta: „Minden, amit látunk, annak árnyéka, amit nem látunk."

A 2.700 lakosú Szakoly község az elmúlt évtizedben megjárta a mennyet és a poklot, hiszen a Nyírség mintafaluja egyik napról a másikra hírhedté vált, elsősorban a polgármester bírósági ügyei miatt, mindeközben az önkormányzat adósságspirálba gabalyodva már nem tudta elkerülni az adósságrendezési eljárást.

A 11 évvel ezelőtti választásokat követően az önkormányzat adósságállománya folyamatosan növekedett, majd jelentős szállítói tartozás halmozódott fel 2010-től, melynek következtében az önkormányzat elindult a dekadencia lejtöjén.

A likviditási helyzet ezt követően sem javult, sőt minden évben csak emelkedett a szállítói tartozás összege. 2012-ben már több mint 76 millió forint ilyen jellegü tartozása volt. Az állami normatíva csak az intézmények müködését biztosította, a rendkívüli mértékủ szállítói tartozás és az azzal szoros összefüggésben lévő fedezet nélküli kötelezettségvállalások megpecsételték az

\footnotetext{
* DOI 10.21867/KjK/2018.2.5.

${ }^{1}$ Dr. Gyirán Zoltán PhD, jegyzö,

2 A Tiszabő adósságrendezési eljárásával kapcsolatban lásd részletsebben a Jegyző és Közigazgatás 2017. decemberi számában megjelent tanulmányt.

${ }^{3}$ A szerző részletesebb esettanulmánya a szakolyi adósságrendezési eljárásról szóló a Jegyző és Közigazgatás 2017/2. számában jelent meg.
} 
önkormányzat sorsát. Már ekkor meg kellett volna indítani az adósságrendezést, de a település vezetése ettől teljes mértékben elzárkózott, annak ellenére, hogy a pénzügyi szakemberek ezt folyamatosan szorgalmazták.

A helyzetet tovább súlyosbította a likvidhitel felvétele, mely évente ismétlödött annak ellenére, hogy sorozatosan nem került visszafizetésre éven belül. Emiatt már a 2014. évi éves beszámoló elkészítésénél is probléma adódott,.Az államháztartás számviteléről szóló kormányrendelet értelmében ${ }^{4}$ nem lehet költségvetési évet követően esedékes kötelezettségvállalást, más fizetési kötelezettséget nyilvántartani, nem lehet a „K9112 Likviditási célú hitelek, kölcsönök törlesztése pénzügyi vállalkozásnak" rovaton szerepeltetni. A beszámoló e során hozott adat ugyanis a jogszabályi rendelkezésekkel ellentétes gyakorlatot takar.

A Magyarország gazdasági stabilitásáról szóló törvény alapján ${ }^{5}$ a naptári éven belül lejáró adósságot keletkeztető ügylethez, így a likvid hitelről szóló adósságügylet megkötéséhez is, nincs szükség a Kormány hozzájárulására. Abban az esetben, ha a visszafizetés mégsem történik meg az év végén, akkor az már nem minősül éven belüli hitelnek, azaz a megkötéshez előzetes kormányzati hozzájárulást kellett volna kérni. Szakoly Község Önkormányzata esetében éven belüli hitel került felvételre, amelyhez nem volt szükség hozzájárulásra. Az ilyen jellegü hitel esetében, a jogkövető magatartás esetén a hitel visszafizetésre kerül év végéig. Akkor még technikailag megoldható volt, hogy a likvid hitel (mely szabályosan nem került visszafizetésre előző év december 31-ig) szerepeljen a beszámolóban, viszont a 2015. évről szóló beszámoló elkészítésénél erre már nem volt lehetőség, amiről a Nemzetgazdasági Minisztérium tájékoztatta is az önkormányzatot, felhívva a figyelmét arra, hogy a jövőben az ilyen jogszabályi rendelkezéssel ellentétes joggyakorlattól tartózkodjon.

A pénzügyi ügyintézö ${ }^{6}$ már 2014-ben is több alkalommal tájékoztatta a polgármestert, hogy a hitelt vissza kell fizetni december 31-ig. Ezt megtette 2015-ben is, de eredménytelenül, mivel a polgármester döntése alapján ignorálva a folyamatos jelzéseket - a likvid hitel visszafizetése helyett decemberben a tárgyhavi béreket fizették ki. ${ }^{7}$

\footnotetext{
4 4/2013. (I.11.) Kormányrendelet az államháztartás számviteléről (Áhsz.) 43. § (7a) bekezdés b) pontja.

5 2011. évi CXCIV. törvény Magyarország gazdasági stabilitásáról (Gst.) 10. § (3) bekezdésének c) pontja.

${ }^{6}$ A képviselö-testületi dokumentumokból kiderül, hogy a pénzügyi ügyintézővel szemben 2016 ban fegyelmi eljárást indítottak, majd pedig büntető eljárás kezdeményezéséröl is döntött a szakolyi képviselö-testület.

${ }^{7}$ Érdekességként említhető meg, hogy már a a korábbi szakolyi jegyző is több jelzéssel élt, illetőleg feljelentést is tett a gazdálkodással kapcsolatos rossz intézkedések miatt.
} 
Ezt követően 2016. áprilisától a központi támogatások finanszírozása felfüggesztésre került. ${ }^{8} \mathrm{Az}$ előző évek gazdálkodásával előidézett súlyos likviditási problémák mellett, a normatíva finanszírozás felfüggesztése után az önkormányzati, valamint az intézményi dolgozók bérének kifizetése sem volt biztosított. Ekkor döntött úgy a képviselö-testület, hogy a közfoglalkoztatás finanszírozására biztosított előleget az elkülönített alszámláról átvezeti, és abból finanszírozza a béreket. Ez megint csak törvényellenes döntés volt, hiszen a közfoglalkoztatás finanszírozására biztosított előleg céltól eltérő felhasználásáról döntöttek.

Mint ahogyan az várható volt, Szakoly esetében is érvényesült Murphy törvénye, azaz ami bekövetkezhet, az be is fog következni: egy közfoglalkoztatással kapcsolatos ellenörzést követően 2016 öszén, a szabálytalan felhasználás miatt a közfoglalkoztatás finanszírozását megszüntették és a szabálytalan felhasználás időpontjára visszamenőleg visszakövetelték a támogatási összeget.

Időközben a 2015. évi beszámoló elkészült, de szakmai aláíró nem volt, és a likvid hitellel kapcsolatos jogi aggályok miatt azt a jegyző sem írta alá. Az elmaradt normatíva folyósítása megtörtént, de a helyzetet ez sem javította lényegesen. A bérfizetések ezt követően sem voltak biztosítva, több alkalommal is késtek. A 2016-ban felvett likvid hitel sem került visszafizetésre; januártól pedig több hónapig nem kaptak a dolgozók fizetést.

Természetesen a központi finanszírozás mellett egyéb központi forrásokban is részesült az önkormányzat: adósságkonszolidáció címén 58.770 .000 forint, míg az utolsó ÖNHIKI támogatás során 40.869 .000 forint támogatást kapott a helyhatóság a kormany.hu adatai szerint. A szükséges forrás tehát rendelkezésre állt a tartozások jelentős részének kiegyenlítéséhez.

Szakoly Község Önkormányzatának Képviselö-testülete 2017. február 6-án 37/2017. (II.06.) képviselö-testületi határozatával ${ }^{9}$ egyfajta kényszerü pálfordulásként mégis felhatalmazta a polgármestert az adósságrendezési eljárás azonnali kezdeményezésére; így a polgármester 2017. február 14-én benyújtotta az adósságrendezési eljárás megindítására irányuló kérelmét a Nyíregyházi Törvényszékre. Másfél hónap múltán, március 30-án jelent meg a Cégközlönyben a Nyíregyházi Törvényszék végzése ${ }^{10}$ Szakoly Község Önkormányzata adósságrendezése megindításának közzétételéröl. A végzés - a törvényben meghatározott kötelező elemek mellett - rendelkezett a pénzügyi gondnokról is.

\footnotetext{
${ }^{8}$ Figyelemmel a Mötv. 111/A. §-ában foglaltakra.

${ }^{9}$ Tekintettel a Mötv. 121. §-ában, valamint a Har. 4. § (1) bekezdésében és 5. § (1) bekezdésében foglaltakra.

10 8.Apk.2/2017/7. számú végzés, mely 2017. március 6-án jogerőre emelkedett.
} 
A szakolyi polgármester beszámolójából egyértelmüen látszik, hogy az önkormányzat már 2016. április 8-án kritikus helyzetben volt, hiszen a polgármester úgy fogalmazott, „a gond orvoslása nem lehetetlen, de még az sem biztos, hogy sikerül ..."

Persze kérdésként merül fel: mi volt az a bizonyos ,gond"? A polgármester elmondása szerint - a pénzügyi ügyintéző okozta felelőtlenség miatt - az önkormányzatnak nem volt költségvetési beszámolója, melynek hiányában központi támogatás sem illette meg az önkormányzatot. A Magyar Államkincstár Szabolcs-Szatmár-Bereg Megyei Igazgatósága természetesen értesítette minderről a polgármestert, aki a képviselő-testület elé terjesztette az ügyet. Akkor még abban reménykedtek, hogy a probléma „orvosolható”.

A hathatós segítséget elsődlegesen könyvelő cégektől várták, amelyek közül az első „kiderítette”, hogy a könyveléssel 2015 óta gondok vannak; majd a harmadik könyvelő cég ötmillió forintért elvállalta, hogy újrakönyveli tételről tételre a 2014. és 2015. költségvetési évet. Mire teljesítették a megbízást már a negyedik havi normatíva maradt el, amit csak súlyosbított, hogy a Kincstár 3,2 millió forintra büntette a késlekedő helyhatóságot.

$\mathrm{Az}$ élet azonban nem állt meg Szakolyban. A polgármester mindent elkövetett, hogy ne maradjanak bér nélkül az önkormányzati foglalkoztatottak. Ezt két hónapig külső segítséggel, két hónapig pedig - a finis sanctificat media leple alatt - „kis könyvelési csiki-csukival” sikerült megoldani: a közfoglalkoztatottak munkabérét tartalmazó elkülönített számláról egyszerüen átvezették az összeget az önkormányzat költségvetési főszámlájára. S persze ezzel minden rendben is volt, hiszen a képviselö-testület minderről határozatot is hozott, sőt a tiszteletdíjukról is lemondtak a pénzügyi nehézségek megoldásáig. ${ }^{11}$ Augusztus végén aztán azzal szembesült a polgármester, hogy a fentebb említett elkülönített számlára sem érkezett meg a várva várt bértámogatás.

A javított beszámoló elfogadását követően az önkormányzat megkapott kéthavi normatívát, amit azonnal átvezettek a több mint 250 közfoglalkoztatott bérét tartalmazó elkülönített számlára. Ezzel azonban az volt a „gond”, hogy központi forrásból nem lehet közfoglalkoztatotti bért finanszírozni.

2016. szeptember közepén - a lehetséges adósságrendezési eljárás fényében de lege lata - a Szabolcs-Szatmár-Bereg Megyei Kormányhivatal

\footnotetext{
${ }^{11}$ A képviselői tiszteletdíjról való lemondás ebben az esetben azért „érdekes”, mert az Mötv. 35. § (2) bekezdésének második mondata értelmében „Az önkormányzati képviselő számára történő tiszteletdíj megállapítása nem veszélyeztetheti az önkormányzat kötelező feladatai ellátását.” $S$ mivel a szakolyi képviselők évek óta likvid hitel felvételéről határoznak, tisztában kellett lenniük azzal, hogy az önkormányzat likviditási problémája miatt a kötelező feladatok ellátása veszélyeztetett.
} 
közleményben tudatta a kormánymegbízotti állásfoglalást, ${ }^{12}$ mely szerint a „Magyarország helyi önkormányzatairól szóló 2011. évi CLXXXIX. törvény (Mötv.) 115. § (1) bekezdése értelmében a helyi önkormányzatok gazdálkodásának biztonságáért a képviselö-testület, a gazdálkodás szabályszerüségéért a polgármester felelös." Ehhez természetesen idézhette volna az Mötv. 112. § (2) bekezdését is, mely szerint „A helyi önkormányzat veszteséges gazdálkodásának következményei a helyi önkormányzatot terhelik, kötelezettségeiért a központi költségvetés nem tartozik felelösséggel." A kormánymegbízott ezzel a nyilatkozattal egyértelmüsítette a szakolyi vezetéssel, hogy nem marad más lehetőségük, mint az adósságrendezési eljárás kezdeményezése.

2016. december 15-én aztán úgy tünt, hogy megérkezett a megígért kormányzati szubvenció: a szakolyi helyhatóság ugyanis 16.695 .019 forint vissza nem térítendő támogatásban (REKI) részesült a Belügyminisztériumtól az elmaradt októberi munkabérek fedezeteként.

A színfalak mögött azonban valami egészen más történhetett, melynek első jeleként 2016 novemberében a jegyző - mielőtt véglegesen diszkreditálták volna - nyújtotta be a lemondását, majd 2016 decemberében a pénzügyi ügyintéző és az adóügyi ügyintéző mondott le, 2017. január 31-én pedig a pénzügyi-gazdálkodási ügyintéző távozott közös megegyezéssel. Öket még egy köztisztviselő követte 2017 márciusában.

Ilyen körülmények között és ennyire „foghíjas” hivatali gárda mellett foglalta el hivatalát az új - a jelenlegi polgármester regnálása óta ötödik jegyző 2017. február 1-jén. Az új szakolyi jegyző elsődleges feladata a távozó köztisztviselök pótlása volt, melynek eredményeként márciusban egy adóügyi ügyintézőt, áprilisban pedig két pénzügyi ügyintézőt nevezett ki. A feladatát lényegesen nehezítette, hogy a polgármester és a távozó köztisztviselők között kialakult rossz viszony következtében az új hivatalvezető csak kevés információhoz jutott hozzá, sőt belépési kódokat sem kapott meg. ${ }^{13}$

A hivatali személyi állomány, ,átrendeződése" mellett a képviselötestületben is megmozdult valami, melynek első momentumaként az egyik független önkormányzati képviselö ${ }^{14}$ a 2017. március 28-i képviselö-testületi ülésen bejelentette lemondását, amit a helyi választási bizottság 1/2017. (IV.05.) HVB határozatával vett tudomásul. A település védőnője, mint önkormányzati

12 http://www.szon.hu/a-polgarmester-es-a-kepviselok-felelossege/3188037 (letöltés dátuma: 2018. január 2.)

${ }^{13}$ Ezzel kapcsolatosan azt valószínüsítem, hogy az új szakolyi jegyzőnek azért nem adták meg a korábban használt belépési kódokat, mert több belépési azonosító esetén nincs átadás, azok ugyanis felhasználóhoz (személyhez) kötöttek, így ilyen esetben a távozó kódját törli a programot üzemeltető, a feladat ellátásával megbízott köztisztviselő pedig kér saját részére új kódot.

${ }^{14}$ A Mötv. 30. §-a alapján. 
képviselö javaslatot tett arra, hogy a kialakult helyzetre tekintettel a képviselötestület név szerinti szavazással és minősített többségü döntésével oszlassa fel magát. ${ }^{15} \mathrm{~A}$ polgármester azonban nem tett indítványt a javaslat napirendre vételére, melynek következtében a képviselő szóban és írásban is bejelentette lemondását.

Az, hogy mi rejtőzhet még a kulisszák mögött, s az eljárás befejezéséig hány csontváz fog még kizuhanni a helyhatóság szekrényeiből, nem tudható. Mindenestre a legfontosabb dolog egyelöre az, hogy az önkormányzat likviditása normalizálódjon.

A történet ezen a ponton természetesen nem ért, nem érhetett véget, hiszen az eljárás még hátra van. Bízom benne, hogy Szakoly Község Önkormányzata pénzügyileg-gazdaságilag megerösödve, a prudens gazdálkodáshoz visszatérve, s a szükséges következtetéseket levonva folytatja a jövőben a település fejlesztését, amely mellett ismét érvényesülnek majd a populizmus elvei. S bízom abban is, hogy az adósságrendezést követően Szakoly ismét a Nagykállói Járás egyik mintafaluja lesz.

\section{Források jegyzéke:}

- 2011. évi CXCIV. törvény Magyarország gazdasági stabilitásáról

- 2011. évi CLXXXIX. törvény Magyarország helyi önkormányzatairól

- 4/2013. (I.11.) Kormányrendelet az államháztartás számviteléröl

- Szakoly Község Önkormányzatának 2017. február 6-i 37/2017. (II.06.) képviselő-testületi határozata

- Nyíregyházi Törvényszék 8.Apk.2/2017/7. számú végzése

- http://www.szon.hu/a-polgarmester-es-a-kepviselokfelelossege/3188037

${ }^{15}$ A Mötv. 55. § (1) bekezdésében foglaltak szerint. 